\title{
(息)
}

Citation:

Dixey, R and Woodall, $\mathrm{J}$ (2012) The significance of 'the visit' in an English category-B prison: Views from prisoners, prisoners' families and prison staff. Community, Work and Family, 15 (1). 29 - 47. ISSN 1366-8803 DOI: https://doi.org/10.1080/13668803.2011.580125

Link to Leeds Beckett Repository record:

https://eprints.leedsbeckett.ac.uk/id/eprint/99/

Document Version:

Article (Accepted Version)

The aim of the Leeds Beckett Repository is to provide open access to our research, as required by funder policies and permitted by publishers and copyright law.

The Leeds Beckett repository holds a wide range of publications, each of which has been checked for copyright and the relevant embargo period has been applied by the Research Services team.

We operate on a standard take-down policy. If you are the author or publisher of an output and you would like it removed from the repository, please contact us and we will investigate on a case-by-case basis.

Each thesis in the repository has been cleared where necessary by the author for third party copyright. If you would like a thesis to be removed from the repository or believe there is an issue with copyright, please contact us on openaccess@leedsbeckett.ac.uk and we will investigate on a case-by-case basis. 
The significance of 'the visit' in an English category-B prison: views from prisoners, prisoners' families and prison staff

Rachael Dixey

Centre for Health Promotion Research

Faculty of Health

Leeds Metropolitan University

James Woodall

Centre for Health Promotion Research

Faculty of Health

Leeds Metropolitan University

Abbreviated title: The significance of 'the visit'

Address for correspondence:

James Woodall

Centre for Health Promotion Research

Faculty of Health

Leeds Metropolitan University

Queen Square House

LS2 8AF

Tel: 01138124436

e-mail: j.woodall@leedsmet.ac.uk 


\title{
The significance of 'the visit' in an English category-B prison: views from prisoners, prisoners' families and prison staff
}

\begin{abstract}
A number of claims have been made regarding the importance of prisoners staying in touch with their family through prison visits. Firstly from a humanitarian perspective of enabling family members to see each other, but also regarding the impact of maintaining family ties for successful rehabilitation, reintegration into society and reduced re-offending. This growing evidence base has resulted in increased support by the Prison Service for encouraging the family unit to remain intact during a prisoners' incarceration. Despite its importance however, there has been a distinct lack of research examining the dynamics of families visiting relatives in prison.
\end{abstract}

This paper explores perceptions of the same event - the visit - from the families', prisoners' and prison staff's viewpoints in a category-B local prison in England. Qualitative data was collected with thirty prisoners' families, sixteen prisoners and fourteen prison staff, as part of a broader evaluation of the visitors' centre (Dixey and Woodall, 2009). The findings suggest that the three parties frame their perspective of visiting very differently. Prisoners' families often see visits as an emotional minefield fraught with practical difficulties. Prisoners can view the visit as the highlight of their time in prison and often have many complaints about how visits are handled. Finally, prison staff see potential security breaches and a major organisational operation. The paper addresses the current gap in our understanding of the prison visit and has implications for the Prison Service and wider social policy. 


\section{The significance of 'the visit' in an English category-B prison: views from prisoners, prisoners' families and prison staff}

Introduction

This paper examines the experience of visits between male prisoners and their families, from the point of view of the family member, the prisoner, and members of prison staff. A number of claims have been made regarding the importance of prison visits, firstly simply from a humanitarian perspective of enabling family members to see each other, but also in policy terms regarding successful rehabilitation and reintegration into society. Prison visits however, are the site of disagreement, concern and emotion, and could be viewed very differently by the differing stakeholders. This paper takes the opportunity to explore these varying views, by presenting data derived from a study whose central aim was to evaluate a prison visitors' centre based at a large category-B prison in the north of England.

In almost all economically developed countries, the prison occupies a prominent place in the politics of crime control and symbolises the apex of the criminal justice system (Crewe, 2009; Sparks, 2007). Within England and Wales there are 140 prison establishments which are functionally as well as geographically diverse (The Centre for Social Justice, 2009). Prisons are broadly categorised as being open or closed institutions; open prisons (often referred to as category-D prisons), for example, are characterised by low levels of security and allow opportunities for offenders to conduct work outside of the prison. Most prisons, however, are closed establishments and security driven and do not allow such levels of freedom. Closed institutions are further classified as being either category-C, category-B or high security institutions. The majority of prisoners are located in category- $\mathrm{C}$ prisons, 
though prisoners are usually sent to local category-B prisons on remand (i.e. awaiting trial) or upon sentencing (The Centre for Social Justice, 2009). According to recent figures, approximately 83,000 offenders currently reside within prison establishments in England and Wales (Ministry of Justice, 2010). Estimates suggest that if recent sentencing trends continue, the prison population will exceed 98,000 by 2013 (de Silva, Cowell, Chow, \& Worthington, 2006). Clearly, as the prison population expands, as too does the number of prisoners' families (including children) being affected.

The loss of the family member from the home and/or as a bread-winner as a result of imprisonment can be a catastrophic occurrence (in some instances of course, it may be that the family is relieved, depending on the nature of the relationship and of the crime). Visiting the family member therefore becomes a powerful experience filled with conflicting emotion. Codd (2008, p152-153) has described prison visits as: "...the lynchpin of contact between prisoners and their families, [they] provoke joy and unhappiness in almost equal measure. They provoke joy at beingbriefly - reunited with a parent, partner, child or friend and also anxiety, stress and sometimes unhappiness prompted by, for visitors, difficult travel arrangements, complex prison policies, or simply an unhappy or difficult meeting with the prisoner."

Although the family visit has been described as the 'lynchpin' of contact between prisoners and their relatives (Codd, 2008), how families maintain ties when a member enters prison has not been well researched, especially from the perspective of the prisoner (Codd, 2008).

How family ties are maintained is not well-researched per se, let alone among groups of offenders. Visiting relations at particular times of the year such as at significant festivals like Christmas or Eid, is part of the culture of many countries; however, the 
sociology of family visiting is relatively under explored in 'normal' family life, and in complex societies where changing forms of technology (such as skype) have enabled new ways of keeping in touch. There is some research where family members are absent from home, e.g. when admitted to hospital. Ross et al. (1997) examined the visiting experiences of wives whose husbands had been admitted to long-term care institutions; Bauer (2006) explored the role of family visiting from the perspective of nursing home staff and Thomas (2001) investigated patients' perceptions of family visits in a specialist palliative care unit.

The paucity of research within the prison setting may be, amongst other things, due to the multi-layered, convoluted and time-consuming process of accessing prisons for research (Carter, 1994; Collica, 2002; Drake, 1998; Hart, 1995; Harvey, 2008; Hodgson, Parker, \& Seddon, 2006; Jupp, 1989; Kirby, 2007; Schlosser, 2008; C. Smith \& Wincup, 2000, 2002; Trulson, Marquart, \& Mullings, 2004; Tunnell, 1998). It is important, however, to understand the role and significance of prison visits, especially due to the importance attached to the maintenance of family ties by, for example, the Prison Service in England and Wales (Light \& Campbell, 2006). This is clearly emphasised in the prison rules which state:

"Special attention shall be paid to the maintenance of such relationships between a prisoner and his family as are desirable in the best interests of both." (Rule 4 of the Prison Rules, 1999)

The importance placed on visits by the Prison Service is supported by the wider literature. It has long been held that enabling prisoners to maintain family ties whilst incarcerated offers a series of benefits both during and after confinement (Bales \& Mears, 2008). Firstly, research indicates that family contact reduces the likelihood of prisoners re-offending. This is particularly important given that $47 \%$ of adult prisoners are reconvicted within one year of being released, increasing to $60 \%$ for those serving sentences of less than 12 months (Prison Reform Trust, 2009). 
Ditchfield (1994) demonstrated that prisoners without active family support are between two and six times more likely to re-offend within the first year of release than those with family support. Bales and Mears (2008), in their U.S. based study, reported that family visits reduce and delays recidivism, with visits from spouses producing a more pronounced reduction.

Secondly, family contact is associated with successful resettlement. UK Home Office research revealed that $37 \%$ of prisoners who had at least one visit from a member of their family had either employment, training or education arranged on release from prison, compared with $16 \%$ of those not receiving visits (Niven \& Stewart, 2005). Thirdly, a prisoner's mental health is often contingent on his contact with the outside world (Woodall, Dixey, Green, \& Newell, 2009). The presence of visitors can 'normalise' the prison environment and function as a reminder of the outside world and its associated responsibilities (Hairston, 1991; Mills, 2005). Regular visits can improve the transition back into the community, lowering levels of 'institutionalisation' as prisoners are not completely immersed in the prison sub-culture (Codd, 2008; Gordon, 1999). Finally, where children remain in contact with their imprisoned father, studies show that the well-being of these children is often higher than those children who do not visit. This may be because, amongst other things, visiting allows children to comprehend the context of their father's imprisonment (Johnston, 1995).

Though positive benefits of family visiting and contact have been identified, some caution is needed. Clearly, not all family contact has a positive influence for prisoners. Green (2004) suggests that in some cases the family may have a detrimental and harmful influence. In the case of young offenders, it could be argued that in some instances family influences may reinforce criminal activity as opposed to condemning it (Codd, 2007). Nevertheless, for many prisoners the case for maintaining family ties is strong and heavily supported by research evidence. 
There have been calls in the literature to better understand the prison visit from varying perspectives (Codd, 2008; Mills, 2005; Tewksbury \& DeMichele, 2005). Tewksbury and DeMichele (2005), for instance, recommend that research should be conducted in various prison facilities to gain further insight into the process of visiting a relative. Mills (2005) also suggests that more attention should be paid to prisoners' own views on family ties and the visits process. Similarly, prison staff have been largely under-represented, reiterating the assertion that prison staff are often the "invisible ghosts of penality" (Liebling, 2000, p.337). This paper aims to rectify this by exploring the perspectives of the three parties - families, prisoners and staff. Whilst it is acknowledged that prisoners receive different types of visit throughout their period of incarceration, for example legal visits from solicitors, this paper only concerns visits made by family members.

\section{Methodology}

The findings presented in this paper are taken from a broader evaluation of a prison visitors' centre in a busy male category-B prison in England holding approximately 1200 prisoners (XX, 2009). Category-B prisoners have been defined as:

"Prisoners for whom the very highest conditions of security are not necessary, but for whom escape must be made very difficult." (Leech \& Cheney, 2002, p.283)

The evaluation was conducted by two researchers, both with experience of research in criminal justice settings, who were commissioned by the visitors' centre to evaluate their services and the impact this had on prisoners' families, prisoners and prison staff. Whilst the number of visits sessions can differ according to the specific prison, at this particular establishment there are thirty visits sessions per week comprising 
four sessions seven days per week, in addition to two evening visits sessions. Each visits session can hold a maximum of twenty-seven prisoners and three adult visitors per prisoner.

Data for the evaluation was generated using interviews and focus groups with prisoners' families, prisoners and prison staff. Further details concerning the methodological approach with each group will be outlined in detail.

\section{Prisoners' families}

Eliciting the views of prisoners' families in a qualitatively driven way was a key part of the evaluation. This allowed the vivid realities of prison visiting and the process of maintaining family ties to be illuminated using the voices of the family members themselves. Short semi-structured interviews were conducted with thirty family visitors; the majority of these visitors were females visiting their husband, boyfriend or son $(n=28)$; only two male visitors were interviewed. Though it is acknowledged that this may not be representative of the profile of family visitors at other prison establishments, the high female representation was to be expected, as prison visitors' centres have traditionally been seen as 'female spaces' (Condry, 2007). To capture the views of a broad range of visitors, interviews were conducted during weekday and weekend visits and during morning and afternoon visiting sessions. Broadly speaking, the participants were family members of the prisoners they were visiting and, for the rest of the article, will be referred to as 'prisoners' families' or simply 'visitors'. Whilst it was the intention to include prisoners' children's perspectives on visiting, this proved difficult as parents were often reticent in allowing their children to speak to unknown researchers. 
Prisoners' families were invited to take part in a short interview as they arrived in the visitors' centre prior to visiting. Print materials had been left in the centre and, in most cases, prisoners' families had read this information on previous visits and were aware of the research activity taking place. Often prison visitors did not have the inclination to spend time being interviewed, as understandably, their primary focus was on visiting their relative. Researchers were sensitive to this and an 'informal approach' to recruiting prisoners' families was adopted.

A fundamental concern of the authors was ensuring that potential participants were able to give informed consent free from any pressure or perceived pressure. It was explained prior to interview that the researchers were independent of the prison. The aims of the research were explained as were issues of confidentiality, anonymity and the right to withdraw from the interview at any point. Where permission was granted by participants the interviews were audio recorded.

\section{Prisoners}

Three focus groups with sixteen prisoners were conducted. It can be argued that focus groups are particularly appropriate in this particular research setting as focus groups can overcome the poor literacy levels that are reported in this group. The composition of the focus groups was decided by prison staff to reflect the diversity of prisoners within the establishment. It is recognised that this was a limitation, as prison staff may have been inclined to 'handpick' prisoners; however, this was a pragmatic decision so that the evaluation could be conducted within the agreed timeframe. The composition of the focus groups were as follows: one group was comprised exclusively of vulnerable prisoners ${ }^{1}(n=5)$, a second focus group with

\footnotetext{
${ }^{1}$ Vulnerable prisoners are those who are at risk of attack from other prisoners by nature of their offence or vulnerability
} 
black and minority ethnic prisoners $(n=5)$ and a third group drawn from two residential wings in the prison $(n=6)$.

Although the majority of prisoners received regular visits from their family and friends, there were also a proportion of participating prisoners who did not. Furthermore, the diverse nature of the sample allowed discussions to be held with remand and sentenced prisoners, therefore providing alternative perspectives of visiting (remand prisoners are entitled to a greater number of visits than sentenced prisoners). Prisoners were encouraged within the focus group to share opinions and discuss individual experiences in relation to visits and maintaining family connections. Whilst details concerning a prisoner's offence, social background and previous criminal activity were not routinely covered, many men provided reflections on their life, their pre-prison circumstances and their criminal activities. Several prisoners, for example, had served previous custodial sentences and were able to compare and contrast similarities and differences between other prison establishments across the country.

The ethical debates and associated discussions regarding prisoners as research participants has been undergoing somewhat of a revival (Pont, 2008). Clearly, prisoners are a vulnerable sub-section of the population and extreme sensitivities are required when conducting research with them (Liamputtong \& Ezzy, 2005; C. Smith \& Wincup, 2002). This means that an ethically robust strategy is needed (Weaver Moore \& Miller, 1999). Achieving informed consent, for example, is a paramount principle (Noaks \& Wincup, 2004). Throughout this study, it was made explicit to prisoners that engagement with the research held no advantage or disadvantage to them or their period of custody within the institution and the right to withdraw from the study, without providing any reason, was made clear. In addition, whilst audio recording evokes particular meaning for those who come into contact with the 
criminal justice system (as offenders will have been tape recorded as part of providing evidence for a criminal investigation (Noaks \& Wincup, 2004; Wilson, 2006)), all participants agreed to be recorded after permission was granted to use the equipment by the prison management, and all prisoners provided consent.

\section{Prison staff}

As previously mentioned, prison staffs' views are generally less heard within research activity; during this study, however, prison staffs' views on the visits process were uncovered using three focus groups with fourteen prison staff. Prison staff were selected by prison managers after the authors had outlined that a diverse group of prison staff (in terms of age, experience, rank, job role) participating in the focus groups would be beneficial. The authors were aware of the limitations of prison management recruiting staff; nonetheless, and as already mentioned, this was the most suitable approach given the limited resources, access and timeframe of the research.

A diverse set of staff members (with job remits including: security, visits, offender management and resettlement, gate responsibility and work on residential wings) voluntarily participated in three focus group sessions. Two focus groups were conducted inside the prison in a suitable venue and the third focus group was held outside of the prison in an appropriate room within the visitors' centre. Each focus group lasted approximately one hour so that staff were not disrupted significantly from their duties. These sessions were audio recorded after permission and consent was obtained from all participants.

Data analysis 
All focus group and interview recordings were transcribed verbatim and the data were coded and themes identified. Initially this level of analysis was carried out separately by the two authors. The individually identified themes were then discussed between the authors and any discrepancies were considered and resolved. The use of thematic networks, as advocated by Attride-Stirling (2001), was adopted as a systematic way of organising the analysis and providing a hierarchy of appropriate themes. Thematic network analysis is not necessarily a new approach, as it builds on key features found in other forms of qualitative data analysis. Nonetheless, the unique aspect of thematic network analysis is that it constructs web-like matrices, offering insight into the researchers' explicit processes from generating interpretation from text and transcripts. Thematic networks systematically organise basic themes into organising themes and then into overarching global themes which succinctly encapsulates aspects of the data.

Reflecting on the operational realities of prison research

Although prisons are unique and exciting social environments to conduct research, safety, security and surveillance govern all activities. This can mean that planned research activities can be postponed or cancelled without prior warning. Both researchers, for instance, experienced instances when interviews or focus groups were postponed at relatively short notice due to organisational issues, such as when the prison was 'locked down' (i.e. prisoners locked in their cells) because of safety concerns. It was necessary to keep the research in perspective and whilst the importance and overall execution of the activities was of central concern to the researchers, in reality, security and control was (quite rightly) the principal matter for 
the establishments. This was succinctly expressed by Trulson et al. (2004, p.462) who provide a word of caution to prospective prison researchers:

"Remember, you are invading their turf, disrupting their routine, and creating a potential security risk."

\section{Findings}

This section presents the findings derived from the various data collection methods. Results from each group will be reported separately and where necessary direct quotations will be presented to highlight specific issues.

The experiences of prisoners' families

Family members were highly motivated to visit their relative in prison; however, for many, visiting could be traumatic and unsettling. On an emotional level, the process of seeing a son, father, husband, partner or friend within an unfamiliar and daunting environment caused anxiety, stress and worry. Families visiting for the first time were particularly uneasy and apprehensive, with many describing feelings of uncertainty, insecurity and generally not knowing what to expect. Several visitors had based their preconceptions of prison visiting on films and television programmes:

"We didn't expect anything like this, we had the impression that it would be like something off the TV."

The imprisonment of a family member often evoked strong and powerful feelings, especially for those visitors who had no previous contact with the criminal justice system. During the research, several visitors entered the prison feeling angry or resenting the system for taking away their relative. One father was particularly emotional with regard to the conditions of his son's imprisonment: 
"The thing is, I think it's not human having them locked up for twenty-three hours a day, they don't even do that to animals...if you get a dog, it's a guard dog, that guard dog gets let out. These people are locked up all the time, and for what an hour a day, this is absolutely stupid it's going back to the prehistoric times, having people get locked up like this, it's rubbish...the law stinks!"

Prison visiting could be an extremely painful event. Many female visitors described how they had been upset at the thought of a visit, frequently crying days prior to and after contact with their close relative. One mother discussed the contrast between her husband's and her own coping response:

"He bawls and shouts and I just go home quietly and have a good cry, it is very stressful."

From a practical and logistical viewpoint, prison visiting was time consuming and could be repeated on numerous occasions each month depending on the prisoner's visit entitlement. Several families consumed a large portion of their day travelling to the prison, often because of insufficient public transport links. This could be particularly demanding if young children were being brought to see their father. A number of older and disabled visitors found the process of visiting physically tiring and therefore had to limit the contact they had with their family member:

"We have only been able to come once a week...I mean I am disabled as well, so I have got to come when I can. The first visit I couldn't which greatly upset me, but my husband came, and then after that I joined him as and when I could."

Although most families were aware of the assisted prison visits scheme to support the financial costs of visiting, a few visitors were ineligible for the scheme. In general, families found visiting expensive. In most cases outlays would have to be 
made up front and then claimed back later, if eligible to do so. As well as the costs associated with travelling, families also paid for refreshments during the visit, as this prison's policy did not allow prisoners to purchase items within the visits hall. In addition to this outlay, families provided the prisoner with financial support as they viewed the wages prisoners received for working in the prison as insufficient to cover the costs of toiletries, telephone credit and cigarettes from the prison canteen (the 'canteen' is an expression used within the prison to describe the place where prisoners can purchase items).

\section{Prisoners' viewpoint}

Visits were generally seen by prisoners as important events which went some way to counter-balance the negative effects of imprisonment, such as monotony and boredom. For most men, visits were profoundly significant:

"I look forward to visits as there are not many highlights in jail."

"It gives you something to look forward to when you know that your family is coming to see you."

Contact with family and friends were commonly viewed as the focal point of a prisoner's routine. Prisoners eagerly anticipated visiting time, frequently placing a great deal of importance on the occasion, as a visit could act to elevate, temporarily, a prisoner's well-being and function as a buffer against the sometimes stressful and oppressive prison environment. One prisoner described his feelings after a visit from his wife and children:

"You feel refreshed and it just lifts your mood up...just the contact, a cuddle and a kiss and whatever." 
Visits provided an important opportunity to remain in contact with the outside world or, as one prisoner suggested, "a chance to keep check of reality." This contact was seen as beneficial especially when attempting to reintegrate back into society after release:

"When your family comes then you stay in touch with that outside life. You know that there is something out there, but if you are not in touch with your family when you come out you are going to be lost."

Some prisoners suggested that visits, in some way, contributed to temporarily reestablishing their role as a son or husband. Extended family visits, a programme introduced by the prison to enable family contact to be maintained, were particularly welcomed. Several prisoners saw this as dedicated time to be spent with their children, allowing them to momentarily restore their role as a parental figure.

Prisoners did acknowledge the strain placed on their families and understood the difficulties their family faced in maintaining family ties. Several recognised the financial and logistical implications for their families. One prisoner commented:

"They spend more time travelling than they do seeing me. It's one and a half hours to get here and then anything from an hour to forty minutes for the visit."

Often difficulties in maintaining family ties were not financial or logistical; rather, the facilities within the visits room made it less conducive to discussing family issues and preserving family bonds. Prisoners suggested that the physical environment of the visits hall was designed exclusively for maintaining security, rather than for comfort or for creating some level of intimacy. Prisoners often felt that the restrictive rules within the visits hall and the design of the chairs and tables (i.e. both being screwed to the floor for security purposes) made them feel as though they were on a closed rather 
than an open visit (closed visits are where the prisoner and visitor are separated by a glass partition and cannot make physical contact). One prisoner commented:

"Softer chairs, a little round table, instead of a high table, kick board and a chair where you can't move...It's like you are sectioned off away from your family isn't it, even though you are not on closed visits it feels like you are."

A majority of prisoners complained that visits could be shortened due to organisational difficulties moving prisoners from wings to the visits hall, with several voicing irritation and frustration at procedures which limited their family contact time. Prisoners claimed that on numerous occasions they received less than the one hour permitted visit time and, in some instances, they only received around forty minutes. These men were particularly annoyed at the inflexibility of visiting time, where if there had been a delay in moving prisoners, this time would not be added to the end of the visit. Prisoners levelled the causes of delays at prison staff, who they believed "could not be bothered' to collect them on time from the wing.

Several prisoners preferred not to receive visits. Although they acknowledged the value of family contact, they found being separated from their family after the visit too difficult. They opted to serve their custodial sentence with only limited family interaction, choosing instead to communicate by telephone or letter writing. Some prisoners consciously decided to focus their attention away from the outside world whilst in prison, feeling that this made their time easier to manage. Moreover, a few men saw visits and family contact as a painful reminder of the world outside which they were missing.

It was fairly common for prisoners not to allow their children to visit them in prison. This had often been a conscious decision made between the prisoner and his partner in order to protect the feelings and welfare of the child: 
"I have got a four year old son, but I don't want him coming into the prison to see me. That's my choice. He thinks I am away working."

Many men felt uncomfortable at the prospect of their children seeing them in a daunting and unfamiliar environment and some suggested that seeing their child for only a brief period of time could be psychologically damaging. Two prisoners suggested:

“I don't like visits. It's a bit hard and I don't like my son coming up...now and again I may ask for a visit but it's too much shit in my head when he has to go like...it makes my jail a bit easier.”

"Getting him taken away form me, being sat on the other side of the table from him, only having an hour with him, it would kill me, it really would kill me" Where children did visit their father, they were often not old enough to be aware of the circumstances and were rarely told the exact reason why they could not visit more regularly. Many prisoners told their children that the prison was their place of work. One remand prisoner yet to be trialled commented:

"My child is six he always asks me when I'm coming home and you know I can't tell him when I'm coming home. I just say look l'm at work here." Prisoners held mixed views regarding the importance of their family relationships in reducing the likelihood of them re-offending or being successfully rehabilitated. Some prisoners suggested that prisoners' personal attitudes and thinking would be the overriding factor in the probability of re-offending. Some suggested that they had a supportive family infrastructure when they were released from previous sentences but this had not stopped them from committing further crimes:

"I've always had someone to come out to but l've been back in jail, it's just a habit I have."

Despite this, several men suggested that families played a central role in the successful resettlement of offenders released from prison. Successful reintegration 
was reported to be especially likely if family ties had been strong prior to the prisoner's sentence and the bonds had been maintained throughout the sentence by regular visits.

The perspectives of prison staff

From the perspective of prison staff, whether they were supportive of visits or not, visits were primarily a huge logistical operation that demanded careful surveillance and control of both prisoners and their families. Large numbers of visitors entered the prison on a daily basis requiring each individual to be security checked, registered and, if suspicions were raised, searched by staff. One senior prison official highlighted the scale of the visits operation:

"We have thousands of visitors here every year; you know we're bigger than some theme parks!"

Organisationally, visits required careful co-ordination so that both prisoners and their families arrived and then left the visits hall without breaching security policies. Visit 'runners' were prison officers who collected prisoners from their wings to escort them to the visits hall; after the visit, these 'runners' would return the men to their cells or places of work. During the visit, staff would be responsible for ensuring the smooth running and security of the visit and would patrol the visits area during the one hour period.

A criticism noted by a number of staff was the lack of staff continuity in the visits hall. Most prison staff were deployed to work in the visits area only on an infrequent basis, in some cases once every eight weeks. Recommendations were put forward to have a dedicated staff group that worked in the visits hall at all times. These teams would have particular aptitudes, good interpersonal skills and be able to communicate with 
prisoners, prisoners' families and children; in doing so, staff believed that they would build up a more rounded perspective of the prisoner - to see him within the context of his family. Whilst security would always remain paramount, this could be done in a less severe or intrusive way:

"Dedicated visits groups. It works because they spend all their time on visits and they get to know the prisoners and they have that rapport."

This perspective was particularly endorsed by one senior staff member who advocated a less intrusive form of security during visits, which was built upon forming relationships between prisoners and their families. However, this could only be effectively delivered if the same staff worked during prison visits:

"...we take people from the residential units to work on visits, so it is not a set member of staff working in there on a regular basis. I believe that with the right kind of people...you know people that are willing to interact with prisoners and families... we'd take a more decent approach. Obviously we have to maintain security but it can be done a damn sight easier with that approach. I mean we talk in terms of security, how we interact with prisoners, the way that we treat prisoners provides more than sneaking about trying to find things. Prisoners will tell you anything if you talk to them and treat them well."

Visits were a common way in which drugs entered the prison. A primary remit of staff duties during visits was therefore to ensure that this did not happen. Several staff commented that, from their perspective, the prison would be a far easier to manage if there were no prison visits, with the justification being that the security of the prison would be maintained to a higher standard. One suggested that "the vast majority of staff wouldn't miss visits." However, those prison staff working directly with offenders recognised the importance prisoners attached to family contact and most acknowledged the crucial role visits played in the prisoner's life. Staff claimed that if 
prisoners were able to enjoy the interaction with their children and their family then they were often easier to manage:

"If the lads in there are getting better quality visits with their family more often and for longer then they are going to be more settled because they discuss their problems and they can play with their children."

Staff suggested that the "knock-on effect" of positive visits was clear and certainly had an impact on the general atmosphere of the wings:

"If they have a terrible visit we [prison staff] suffer...they come straight back to us and say 'this happened or this happened now sort it'."

Some prisoners could also be particularly vulnerable after a visit, especially if they had received bad news, which staff knew they had to be on the look out for.

\section{Discussion}

This paper has highlighted the differing perspectives of prison visits from the viewpoint of the prisoner, his family and prison staff in one busy category-B prison in England. It has also aimed to fill in some of the knowledge gaps around prison visitation, given the emphasis placed on visits (i.e. their link with improved resettlement and reduced re-offending) by the Prison Service and other organisations working towards the successful rehabilitation and reintegration of offenders.

The findings have shown that the prison visit is socially constructed and has different meanings for the players involved. Social constructionists argue that there is no such thing as an 'objective fact' (Burr, 2003). Indeed, the proposition that the world does not exist as one social reality has been noted by Sykes (1958, p.136) who commented upon the nature of prison research: 
"The realities of imprisonment are, however, multi-faceted; there is not a single true interpretation but many, and the meaning of any situation is always a complex of several, often conflicting viewpoints. This fact can actually be an aid to research concerning the prison rather than a hindrance, for it is the simultaneous consideration of divergent viewpoints that one begins to see the significant aspects of the prison's social structure. One learns not to look for the one true version; instead, one becomes attuned to contradiction." Triangulating data from the three groups (prisoners, families and staff) has not led to 'a true version' of the visit experience, but rather to widely diverging and contested perspectives on the same event, with the players constructing their own versions of 'reality'. Even within the staff, there were not shared versions of knowledge - the 'reality' of visiting was seen very differently by staff who had a more family and prisoner-centred, 'rehabilitative' view of what prison was for, contrasted with those who could, and did, describe families and prisoners in derogatory terms and emphasised the security breaches 'caused' by visits.

For prisoners' families, visits were an ordeal fraught with practical and emotional difficulties. Previous research over the past decade suggests that families visiting prisons have to overcome many barriers in terms of physical, financial and emotional strains (Cunningham, 2001; Loucks, 2004; McEvoy, O’Mahoney, Horner, \& Lyner, 1999; Woodall, et al., 2009). Families experienced a range of emotions including fear, shame, sadness, embarrassment, frustration and loss. Those visiting for the first time were particularly prone to experiencing a cocktail of emotions, whereas those who had been visiting for some time had prior knowledge of the experience and could therefore better manage their feelings.

The distance prisoners' families travel for visits and the associated costs frequently arose as a problem. The assisted prison visits scheme in many ways ameliorates 
some of these issues but does not cover refreshments en route and at the prison (Codd, 2007); often families are either unaware of the scheme or ineligible for financial reimbursement $(X X, 2009)$. Families often felt a duty of care and a need to provide refreshments for their relative during the visit; furthermore, money was often sent by the family to the prisoner to assist him in purchasing items from the prison canteen. Although by providing financial assistance, prisoners' families ameliorated the 'deprivation of goods and services' through providing the prisoner with various commodities (Mills, 2005; Sykes, 1958), this may have placed additional financial pressure on families. Research suggests that women, in particular, may feel a responsibility to care and provide for their relatives in prison (R. Smith, Grimshaw, Romeo, \& Knapp, 2008). For some families, this economic outlay can have damaging consequences; Grinstead et al. (2001) reported that low-income women spent a large proportion of their income (26\%) on prison visiting and other costs of maintaining contact. This can be extremely detrimental, as we know that as prisoners' families frequently suffer financial difficulties as a result of imprisonment (Christian, Mellow, \& Thomas, 2006; Codd, 2008; Light \& Campbell, 2006; R. Smith, et al., 2008).

For most prisoners' families, prison staff are regarded as the public face of the prison service, embodying the power to punish their relatives (Codd, 2008; Garland \& Young, 1979). Our findings validate those of Broadhead (2002), who noted that visitors can be treated as a nuisance, a disruption to the routine and a security threat. Prison staff often saw visits between a prisoner and his family simply as an opportunity to violate prison rules and pass drugs, and did not attach importance of the visit to the prisoners' and family's well-being and long-term future. This reaction to family visitors may be symptomatic of working in a busy category-B prison which accommodates both sentenced and remand prisoners and which has a sizeable turnover of prisoners each week. Consequently, staff may be unable to build up 
extensive rapport or trust with prisoners or their families and therefore resort to a default position which prioritises safety and security. It is the case, of course, that visits have been, and are, an opportunity to breach security, and clearly prison staff must maintain their remit for control and surveillance. However, the way this is implemented could be 'family friendly.' Prison staff during visits have been accused by families of being unsympathetic and intrusive (Woodall, et al., 2009), often acting on their power to maintain the 'them and us' attitude which have prevailed in prisons.

Codd (2008, p.60) noted that prison staff "can make families feel at home, or, in contrast, profoundly unwelcome." Arguably, in a contemporary prison service it is not acceptable that families feel unwelcome when visiting. However, this may be a contributory factor which has seen prison visits declining over the past number of years despite the prison population steadily increasing (Broadhead, 2002; Salmon, 2005). It has been recommended that prison staff should undertake training in issues surrounding the impact of imprisonment on families and children, so that greater trust and understanding can be built (Action for Prisoners' Families, CLINKS, Prison Advice \& Care Trust, \& Prison Reform Trust, 2007).

Prisoners did worry about not seeing their family and about relationships breaking down, as found in other studies (Lester, Hamilton-Kirkwood, \& Jones, 2003), and it is unsurprising that for the majority of prisoners the visit was the main highlight of prison life, often lifting mood and enhancing "emotional survival" (Dodge \& Pogrebin, 2001, p.51). Prisoners had strong views on how visiting could be improved, as very few were satisfied by the visits process, often commenting that the prison facilities were poor and not conducive to promoting family ties and that they were better in other prisons. They were vociferous in arguing that some of the organisational procedures for moving prisoners to and from the visits hall meant that they often did not get their 
full visiting allocation time. Whether this is 'objectively true' or not is unknown, but it indicates that prisoners feel that the time they have with families is not long enough.

From a prisoners' perspective, the family visit is a situation where his identity as an inmate and as a father, husband or son are in sharp focus (Tripp, 2009), and some prisoners actively chose not to receive visits because this focus was too painful. Their decision to serve 'hard time' (Codd, 2008), suggested that it made their time in prison more manageable by 'blocking out' the outside world. For these prisoners it seemed that the visit had a "double edge" (Arditti, 2003, p.131) as, on the one hand, the (sporadic) visit could provide reconnection to the family unit; however, it would also induce a traumatic separation (especially from their children) once the designated visit session was over. This finding is not necessarily new; Cohen and Taylor (1972), citing the work of Maurice Farber, suggested that prisoners who limit contact with the outside world often do so to make their life easier. Cohen and Taylor (1972, p82) note:

"Either one attempts to keep everything going, to continue to live vicariously with wife and children and friends, or one abandons oneself to the prison community. The middle state in which relationships are only tenuously maintained seems least bearable. "

Those who did receive visits were generally reluctant to allow their children to see them. Prisoners and their partners often concocted stories to their children to conceal their incarceration. This was primarily done to protect their children and perhaps not to jeopardise the prisoners' future parental role. Yet research has outlined the benefits of children and parents remaining in contact despite imprisonment. For example, empirical studies show that the well-being of children who visit their father in prison is often higher than those children who do not visit (Johnston, 1995). Therefore, informing prisoners' children about their father's 
incarceration in a sensitive way and with support from relevant professionals may, in some cases, be more beneficial for the child than obscuring the issue.

This paper has suggested that the visit is constructed differently by the key stakeholders - prisoners, their families and prison staff. There is also, in policy terms, a view that visiting is one of the key ingredients of successful rehabilitation. Visiting holds different meanings for each party, and thus the role of visiting in the criminal justice system is contested. Burr (1995, p.4) has suggested that "[A]ll knowledge is derived from looking at the world from some perspective or another, and is in the service of some interests rather than others." It is clear from this research that there are competing interests and it is by no means clear what direction future policy should take. Current policy direction has been largely informed by policy makers, researchers and those concerned with the criminal justice system, but generally not by prisoners and their families themselves. To view the prison visit from the perspective of the prisoner is particularly important, as prisoners' views and accounts are relatively unheard or are restrained during research processes (Ammar \& Weaver, 2005; Hek, 2006). Some prisoners themselves however, held ambivalent views about visiting, as did some staff. Other prisoners were very clear about their importance, even if they framed this purely in terms of wanting to see their families and friends, irrespective of the policy makers' agenda regarding long term rehabilitation. On that latter point, prisoners were not especially convinced about the role of visiting and successful reintegration post-release but they certainly knew that visiting helped them to get through their sentence.

Although prisoners themselves may not see the longer term benefits, research shows that there are substantial gains to be made if prisoners remain in contact with their family during their imprisonment (Bales \& Mears, 2008; Niven \& Stewart, 2005). Regular visiting improves prisoners' mental well-being, improves their resettlement 
back into the community and reduces the likelihood of re-offending. However, despite their importance, we know relatively little about the prison visit. Though previous research has explored the visit from the viewpoint of prisoners' families', very few studies have taken the perspective of the prisoner and prison staff. Further research should investigate the situation in female prisons, as research indicates that women find it problematic to maintain social relationships with their children, family and other supportive infrastructures as $60 \%$ of women are imprisoned outside of their home region (Prison Reform Trust, 2009; C. Smith \& Borland, 1999).

\section{Conclusion}

Prison visits are "an essential component of the rehabilitative process" (Shafer, 1994, p.17), yet very little is known about this event. This paper has illuminated the prison visit by drawing on the views of prisoners' families, prisoners and prison staff in a category-B prison in England. From the prisoners' standpoint, the visit can be the highlight of their time in prison, with the loss of family contact being the most difficult aspect of their punishment to deal with. Prisoners' families can find visiting a major ordeal requiring careful negotiation at emotional, financial and logistical levels. Some prison staff perceived visits primarily as an organisational and security operation with the potential for drugs and other contraband to be brought into the establishment. They saw it as a technical task requiring technical solutions rather than a human endeavour requiring good interpersonal skills. Others, who took a more 'rehabilitative' view of the role of the prison sentence, saw no contradiction between security and family connectedness. Prison staff clearly play a prominent part in the dynamics of visiting, suggesting that their role should be carefully balanced between ensuring security and yet allowing prisoners and their family to reconnect without feeling under constant surveillance and scrutiny. Other recommendations from the 
research include the role of prison visitors' centres as an essential part of a modern prison service as they can considerably support families and also prisoners who want to stay in touch with their relatives (Woodall, et al., 2009). Projected figures indicate that the prison population will continue to grow in England and Wales (de Silva, et al., 2006), which means that more and more families will be potentially interacting with the Prison Service. A greater appreciation of the dynamics of the prison visit can only be beneficial to all of the 'key players' in this situation and contribute towards future policy and planning. 


\section{References}

Action for Prisoners' Families, CLINKS, Prison Advice \& Care Trust, \& Prison Reform Trust (2007). The children \& families of prisoners: recommendations for government. London: APF, CLINKS, PACT, PRT.

Ammar, N. H., \& Weaver, R. R. (2005). Restrained voices: female inmates' views of health services in two Ohio prisons. Women \& Criminal Justice, 16(3), 67-89.

Arditti, J. A. (2003). Locked doors and glass walls: Family visiting at a local jail. Journal of Loss and Trauma, 8(2), 115-138.

Attride-Stirling, J. (2001). Thematic networks: an analytic tool for qualitative research. Qualitative Research, 1(3), 385-405.

Bales, W. D., \& Mears, D. P. (2008). Inmate social ties and the transition to society? Does visitation reduce recidivism? Journal of Research in Crime and Delinquency, 45(3), 287-321.

Bauer, M. (2006). Collaboration and control: nurses' constructions of the role of family in nursing home care. Journal of Advanced Nursing, 54(1), 45-52.

Broadhead, J. (2002). Visitors welcome - or are they. The New Law Journal, 152(5), 7014-7015.

Burr, V. (1995). An introduction to social constructionism (2nd ed.). London:

Routledge.

Burr, V. (2003). Social constructionism (2nd ed.). London: Routledge.

Carter, K. W. (1994). Access. My flexible friend. Prison Service Journal, 93, 30-35.

Christian, J., Mellow, J., \& Thomas, S. (2006). Social and economic implications of family connections to prisoners. Journal of Criminal Justice, 34, 443-452.

Codd, H. (2007). Prisoners' families and resettlement: a critical analysis. The Howard Journal of Criminal Justice, 46(3), 255-263.

Codd, H. (2008). In the shadow of prison. Families, imprisonment and criminal justice. Cullompton: Willan Publishing. 
Cohen, S., \& Taylor, L. (1972). Psychological survival. The experience of long-term imprisonment. Harmondsworth: Penguin.

Collica, K. (2002). Levels of knowledge and risk perceptions about HIV/AIDS among female inmates in New York State: can prison-based HIV programs set the stage for behavior change? The Prison Journal, 82(1), 101-124.

Condry, R. (2007). Stigmatised women: relatives of serious offenders and the broader impact of crime. In F. Heidensohn (Ed.), Gender and justice: new concepts and approaches (pp. 96-120). Collumpton: Willan Publishing.

Crewe, B. (2009). The prisoner society. Power, adaptation and social life in an English prison Oxford: Oxford University Press.

Cunningham, A. (2001). Forgotten families-the impacts of imprisonment. Australian Institute of Family Studies, 59, 35-38.

de Silva, N., Cowell, P., Chow, T., \& Worthington, P. (2006). Home Office statistical bulletin. Prison population projections 2006-2013. London: Crown.

Ditchfield, J. (1994). Family ties and recidivism. Home Office research bulletin No.36. London: Home Office.

Dixey, R. and Woodall, J. (2009) Moving on: an evaluation of the Jigsaw Visitors' Centre. Centre for Health Promotion Research: Leeds Metropolitan University.

Dodge, M., \& Pogrebin, M. R. (2001). Collateral costs of imprisonment for women: complications of reintegration. The Prison Journal, 81(1), 42-54.

Drake, V. K. (1998). Process, perils, and pitfalls of research in prison. Issues in Mental Health Nursing, 19, 41-52.

Garland, D., \& Young, P. (1979). The power to punish: contemporary penality and social analysis. Aldershot: Gower.

Gordon, J. (1999). Are conjugal and familial visitations effective rehabilitative concepts? The Prison Service Journal, 79(1), 119-135. 
Green, D. (2004). Crime reduction: are government policies likely to achieve its declared aims? http://www.civitas.org.uk, accessed 26th March, 2009

Grinstead, O., Faigeles, B., Bancroft, B., \& Zack, B. (2001). The financial cots of maintaining relationships with incarcerated African American men. Journal of African American Men, 6(1), 59-69.

Hairston, C. F. (1991). Family ties during imprisonment: important to whom and for what. Journal of Sociology and Social Welfare, 18(1), 87-104.

Hart, C. B. (1995). A primer in prison research. Journal of Contemporary Criminal Justice, 11(3), 165-176.

Harvey, J. (2008). An embedded multimethod approach to prison research. In R. D. King \& E. Wincup (Eds.), Doing research on crime and justice (2nd ed., pp. 487-500). Oxford: Oxford University Press.

Hek, G. (2006). Unlocking potential: challenges for primary health care researchers in the prison setting. Primary Health Care Research and Development, 7, 9194.

Hodgson, P., Parker, A., \& Seddon, T. (2006). Doing drug research in the criminal justice system. Addiction Research and Theory, 14(3), 253-264.

Johnston, D. (1995). Parent-child visitation in the jail or prison. In K. Gabel \& D. Johnston (Eds.), Children of incarcerated parents (pp. 135-143). New York: Lexington Books.

Jupp, V. (1989). Methods of criminological research. London: Routledge.

Kirby, S. (2007). The contextual researcher: celebrating 'experiential alertness' in grounded theory in prison research. Nurse Researcher, 14(2), 51-65.

Leech, M., \& Cheney, D. (2002). Prisons handbook. Winchester: Waterside Press.

Lester, C., Hamilton-Kirkwood, L., \& Jones, N. K. (2003). Health indicators in a prison population: asking prisoners. Health Education Journal, 62(4), 341-349.

Liamputtong, P., \& Ezzy, D. (2005). Qualitative research methods (2nd ed.). Oxford: Oxford University Press. 
Liebling, A. (2000). Prison officers, policing and the use of discretion. Theoretical Criminology, 4(3), 333-357.

Light, R., \& Campbell, B. (2006). Prisoners' families: still forgotten. Journal of Social Welfare \& Family Law, 28(3-4), 297-308.

Loucks, N. (2004). 'Prison without bars': needs, support and good practice for work with prisoners' families. Tayside: Families Outside.

McEvoy, K., O’Mahoney, D., Horner, C., \& Lyner, O. (1999). The families of politically motivated prisoners in Northern Ireland. The British Journal of Criminology, 39(2), 175-197.

Mills, A. (2005). 'Great expectations?': a review of the role of prisoners' families. Paper presented at the British Society of Criminology Conference.

Ministry of Justice (2010). Prison population \& accommodation briefing for $22 \mathrm{nd}$ January, 2010. London: Ministry of Justice.

Niven, S., \& Stewart, D. (2005). Resettlement outcomes on release from prison in 2003. Home Office Findings No. 248. London: Home Office.

Noaks, L., \& Wincup, E. (2004). Criminological research. Understanding qualitative methods. London: Sage.

Pont, J. (2008). Ethics in research involving prisoners. International Journal of Prisoner Health, 4(4), 184-197.

Prison Reform Trust (2009). Bromley briefings. Prison factfile. London: Prison Reform Trust.

Ross, M. M., Rosenthal, C. J., \& Dawson, P. (1997). Spousal caregiving in the institutional setting: visiting. Journal of Clinical Nursing, 6, 473-483.

Salmon, S. (2005). Prisoners' children matter. Prison Service Journal, 159, 16-19.

Schlosser, J. A. (2008). Issues in interviewing inmates. Navigating the methodological landmines of prison research. Qualitative Inquiry, 14(8), 15001525. 
Shafer, N. (1994). Exploring the link between visits and parole success. International Journal of Offender Therapy and Comparative Criminology, 38(1), 17-32.

Smith, C., \& Borland, J. (1999). Minor psychiatric disturbance in women serving prison sentence: the use of the General Health Questionnaire in the estimation of the prevalence of non-psychotic disturbance in women prisoners. Legal and Criminological Psychology, 4(2), 273-284.

Smith, C., \& Wincup, E. (2000). Breaking in: researching criminal justice institutions for women. In R. D. King \& E. Wincup (Eds.), Doing research on crime and justice (pp. 331-350). Oxford: Oxford University Press.

Smith, C., \& Wincup, E. (2002). Reflections on fieldwork in criminal justice institutions. In T. Welland \& L. Pugsley (Eds.), Ethical dilemmas in qualitative research (pp. 108-120). Aldershot: Ashgate.

Smith, R., Grimshaw, R., Romeo, R., \& Knapp, M. (2008). Prisoners' families: civic virtue and policies of impoverishment. Benefits, 16(1), 3-17.

Sparks, R. (2007). The politics of imprisonment. In Y. Jewkes (Ed.), Handbook on prisons (pp. 73-94). Cullompton: Willan Publishing.

Sykes, G. M. (1958). The society of captives: a study of a maximum security prison. New Jersey: Princeton University Press.

Tewksbury, R., \& DeMichele, M. (2005). Going to prison: a prison visitation program. The Prison Journal, 85(3), 292-310.

The Centre for Social Justice (2009). Breakthrough Britain: locked up potential. London: The Centre for Social Justice.

Thomas, R. (2001). Patients' perceptions of visiting: a phenomenological study in a specialist palliative care unit. Palliative Medicine, 15, 499-504.

Tripp, B. (2009). Fathers in jail: managing dual identities. Applied Psychology in Criminal Justice, 5(1), 26-56. 
Trulson, C. R., Marquart, J. W., \& Mullings, J. L. (2004). Breaking in: gaining entry to prisons and other hard-to-access criminal justice organizations. Journal of Criminal Justice Education, 15(2), 451-478.

Tunnell, K. D. (1998). Interviewing the incarcerated: personal notes on ethical and methodological issues. In K. B. DeMarrais (Ed.), Inside stories: qualitative research reflections (pp. 127-137). New Jersey: Lawrence Erlbaum Associates.

Weaver Moore, L., \& Miller, M. (1999). Initiating research with doubly vulnerable populations. Journal of Advanced Nursing, 30(5), 1034-1040.

Wilson, D. (2006). Some reflections on researching with young black people and the youth justice system. Youth Justice, 6(3), 181-193.

Woodall, J., Dixey, R., Green, J., \& Newell, C. (2009). Healthier prisons: the role of a prison visitors' centre. International Journal of Health Promotion and Education, 47(1), 12-18. 